\title{
COVID-19 IN INTENSIVE CARE
}

\section{Cardiac injury in COVID-19}

\author{
Julie Helms ${ }^{1,2,3}$, Alain Combes ${ }^{4,5^{*}}$ (D) and Nadia Aissaoui ${ }^{6,7}$
}

Patients with coronavirus disease 2019 (COVID-19) can present with a large panel of cardiac manifestations, including myocardial infarction with (type 1) or without (type 2) obstructive coronary artery disease, arterial or venous thromboembolic disease, pericarditis and myocarditis, arrhythmias, acute heart failure, shock or cardiac arrest [1]. The most frequent cardiac abnormality reported in COVID-19 is acute cardiac injury (ACI), defined by cardiac troponin elevation $>99$ th percentile [2]. ACI occurred in as many as $50 \%$ and $21 \%$ of critically ill and hospitalized COVID-19 patients, respectively, rates which were higher than in severe diseases caused by other respiratory viruses [3]. COVID-19 patients with ACI were older (median age 70 years), had increased markers of systemic inflammation, more frequent malignant arrhythmias, shock and need for intensive care unit (ICU) care and higher mortality rates [4], with myocardial injury being the second cause of death after respiratory failure [5]. Furthermore, compared to a preCOVID-19 population, COVID-19 patients with type 1 myocardial infarction had prolonged symptom-to-admission times, more frequent cardiogenic shock and higher mortality [6]. It should also be emphasized that COVID19 patients had frequent cardiovascular comorbidities such as hypertension, obesity, metabolic syndrome and pre-existing coronary artery disease that may have precipitated cardiac complications [1,3-5].

The pathogenic mechanisms underlying cardiac injury in COVID-19 are many (Fig. 1). First, myocardial oxygen supply-demand imbalance in the context of severe hypoxemia, hypoperfusion and shock and stress-induced cardiomyopathy may lead to ACI characterized by

\footnotetext{
*Correspondence: alain.combes@aphp.fr

${ }^{5}$ Service de Médecine Intensive-Réanimation, Hôpital Pitié-Salpêtrière, Assistance Publique-Hôpitaux de Paris, Sorbonne Université, INSERM, UMRS_1166-ICAN, Institute of Cardiometabolism and Nutrition, 47, boulevard de l'Hôpital, 75013 Paris, France

Full author information is available at the end of the article
}

\section{Springer}

elevated troponins and heart dysfunction. Second, both the acute respiratory distress syndrome (ARDS) with reduced lung compliance and pulmonary vascular dysfunction and positive pressure mechanical ventilation are associated with increased right ventricle afterload and a higher incidence of right ventricular dysfunction and acute cor pulmonale [7]. Mechanisms of pulmonary vascular dysfunction in ARDS include non-specific systemic inflammation, endothelial dysfunction and coagulation activation, but also vasoconstriction due to hypoxemia and inflammation, extrinsic compression of vessels, and fibroproliferation due to pulmonary vascular remodeling [7]. Third, specific SARS-CoV-2 interactions with heart cells may also cause cardiac dysfunction. After binding to angiotensin converting enzyme-2 (ACE-2) receptors, the virus elicits a strong activation of the innate immune system, resulting in an intense systemic inflammatory response with release of proinflammatory cytokines. This "cytokine storm" leads to a diffuse endotheliitis and subsequent procoagulant activity. SARS-CoV-2 is responsible for an excessive local and systemic coagulation activation with platelet activation and dysregulated immunothrombosis explaining how patients suffering from COVID-19 might develop in situ pulmonary microthrombi [8], but also pulmonary occlusions (embolisms) in up to $30 \%$ of the most severe patients [9]. Myocardial injury can also result from direct viral lesion of endothelial and/or myocardial cells, although SARS-CoV-2 detection is rare in these cells [8]. Various viral entry receptors, including ACE-2 transmembrane protein, have been found in cardiomyocytes, endothelial cells, smooth muscle cells, and fibroblasts, suggesting that the virus might, directly or indirectly, account for cardiac cytopathic effects, even in individuals with apparently healthy hearts [3]. These cytopathic effects may worsen the inflammation-induced endothelial dysfunction and pro-thrombotic phenotype and be responsible for micro-thrombosis in myocardial tissues. Concomitantly, loss of ACE-2 and hyper-activation of the renin-angiotensin-aldosterone system may contribute to endothelial dysfunction and multiple organ injury, including cardiac failure [10]. 


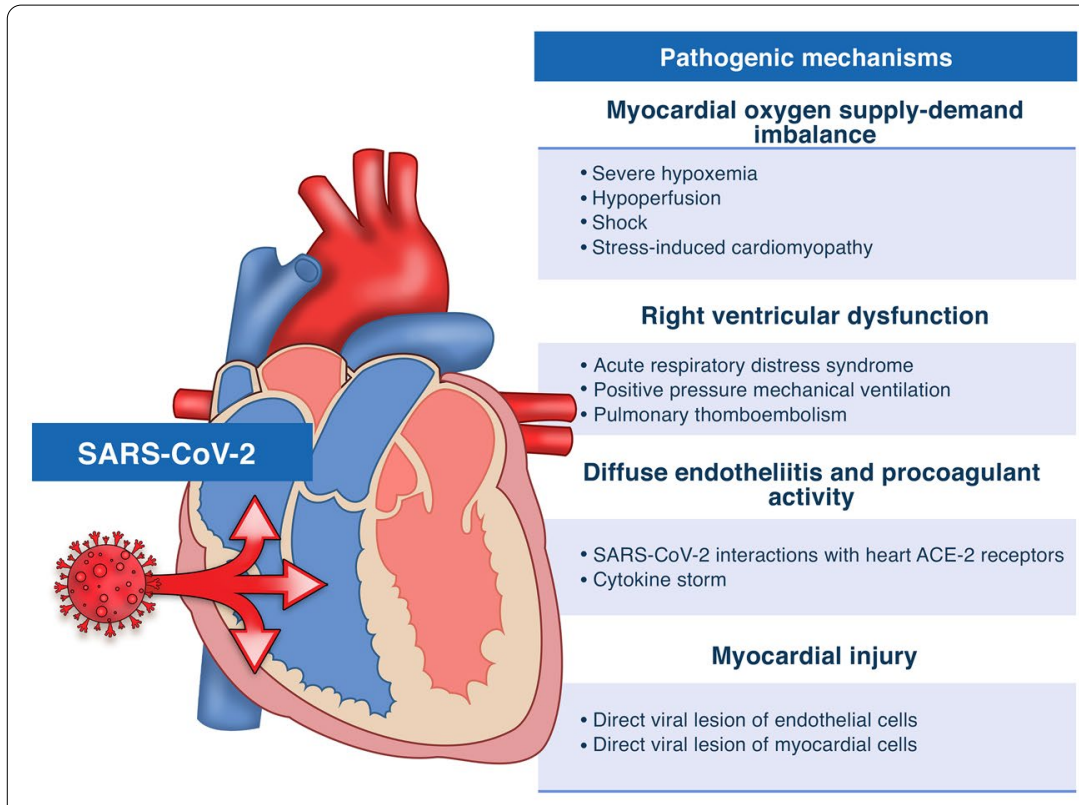

Fig. 1 Overview of myocardial injury mechanisms in critically ill COVID-19 patients

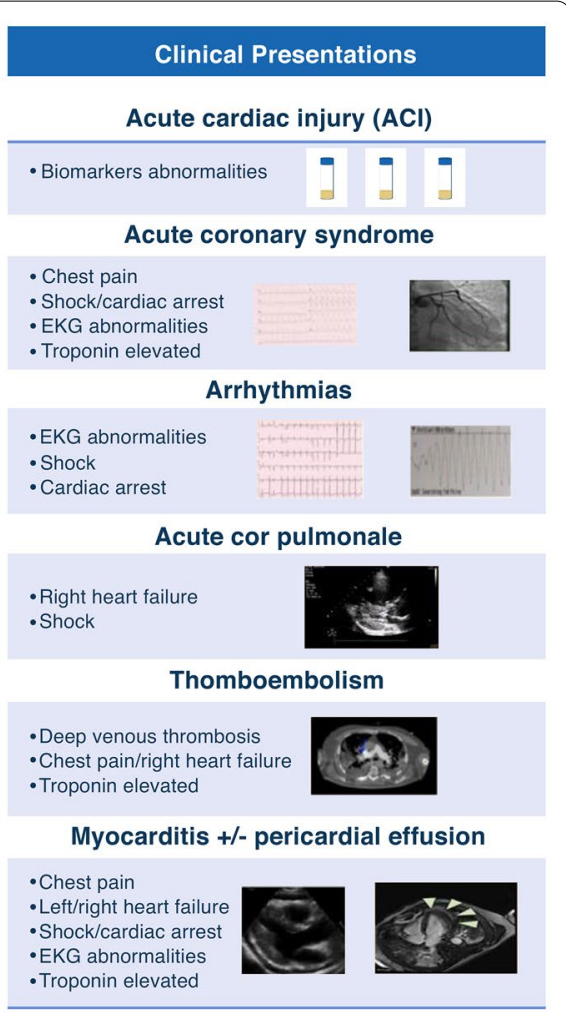

Acute myocarditis has been reported in COVID-19 patients with elevated cardiac troponin, abnormalities on echocardiography (most often altered left ventricular function) and/or electrocardiogram with variable findings, although only few cases were confirmed by endomyocardial biopsy and/or cardiac magnetic resonance [10]. Cardiac histopathological findings in deceased COVID-19 patients mainly combined inflammatory and prothrombotic features, congestive cardiomyopathy, and injuries due to prior conditions, like atherosclerotic coronary artery disease, chronic ischemic cardiomyopathy, myocardial hypertrophy, but only few cases reported focal lymphocytic myocarditis [8]. It should also be mentioned that myocarditis/pericarditis are a rare complication of COVID-19 mRNA vaccinations, especially in young adult and adolescent males, with rates of approximately 12.6 cases per million doses of second dose mRNA vaccine among 12-39-year-olds [11].

Supraventricular and ventricular arrhythmias and conduction disorders are commonly reported in COVID-19 [2]. In a recent worldwide survey assessing 4526 patients, 827 developed arrhythmias (70\% atrial, 20\% ventricular arrhythmias), which were associated with higher morbidity and mortality. Coexisting hypoxia, electrolyte disorders, comorbid conditions and administration of arrhythmogenic medications (e.g., hydroxychloroquine, azithromycin) make it difficult to ascertain the direct and indirect contribution of COVID-19 on cardiac arrhythmias. Data from the national Swedish Registry for Cardiopulmonary Resuscitation also showed that COVID-19 was involved in at least $10 \%$ and $16 \%$ of all out-of-hospital and in-hospital cardiac arrest, respectively, and associated with a significant increase in 30-day mortality [12, 13]. Stress on healthcare systems and delay in seeking medical help, perhaps driven by fear of nosocomial COVID-19 or reduced accessibility to medical care, may have been partly responsible for the higher rates of cardiac complications and cardiac arrest, especially during the first wave of the pandemic.

Cardiac dysfunction has been reported as a complication of the multisystem inflammatory syndrome in children (MIS-C) and young adults, which is a rare complication occurring 2-6 weeks after SARS-CoV-2 infection [14]. It is characterized by fever, nonspecific symptoms such as abdominal pain, vomiting, headache, fatigue and intense inflammation with elevated levels of C-reactive protein, ferritin, troponin, and $\mathrm{N}$-terminal pro-B-type natriuretic peptide. Patients may also have conjunctival injection and rash resembling Kawasaki's disease. In the most severe forms, cardiac failure, shock and multiorgan dysfunction may occur, requiring inotropic and vasoactive drugs and sometime 
temporary mechanical circulatory support. Treatment of this post-viral multisystem inflammatory syndrome associates intravenous immune globulin (IVIG) and glucocorticoids and the evolution is usually favorable.

Lastly, the sustained inflammatory response in COVID-19 might lead to upregulation of genes encoding inflammatory cytokines and extracellular matrix components involved in cardiac fibrosis, contributing to cardiac failure in post-acute evolution of the infection [10]. Indeed, it was observed that 6 months after COVID-19, diastolic without systolic ventricular dysfunction existed only in patients who had experienced myocardial injury during the acute phase of the disease [15].

While myocardial injury in COVID-19 may have various clinical presentations, it is overall associated with high rates of complications and mortality and possible long-term cardiac impairments in survivors. Both pathophysiological mechanisms and long-term evolution of survivors still deserve further investigations.

\begin{abstract}
Author details
${ }^{1}$ Faculté de Médecine, Université de Strasbourg (UNISTRA), Strasbourg, France. ${ }^{2}$ Service de Médecine Intensive-Réanimation, Nouvel Hôpital Civil, Hôpitaux Universitaires de Strasbourg, Strasbourg, France. ${ }^{3}$ INSERM (French National Institute of Health and Medical Research), UMR 1260, Regenerative Nanomedicine (RNM), FMTS, Strasbourg, France. ${ }^{4}$ Institute of Cardiometabolism and Nutrition, Sorbonne Université, Paris, France. ${ }^{5}$ Service de Médecine Intensive-Réanimation, Hôpital Pitié-Salpêtrière, Assistance Publique-Hôpitaux de Paris, Sorbonne Université, INSERM, UMRS_1166-ICAN, Institute of Cardiometabolism and Nutrition, 47, boulevard de l'Hôpital, 75013 Paris, France. ${ }^{6}$ APHP, Hôpital Européen Georges Pompidou, Université de Paris, Paris, France. ${ }^{7}$ Paris Cardiovascular Research Center, INSERM U970, Paris, France.
\end{abstract}

\section{Declarations}

\section{Conflict of interest}

The authors have no conflict of interest to disclose.

\section{Publisher's Note}

Springer Nature remains neutral with regard to jurisdictional claims in published maps and institutional affiliations.

Received: 1 September 2021 Accepted: 9 October 2021

Published online: 2 November 2021

\section{References}

1. Xiong TY, Redwood S, Prendergast B, Chen M (2020) Coronaviruses and the cardiovascular system: acute and long-term implications. Eur Heart J 41:1798-1800. https://doi.org/10.1093/eurheartj/ehaa231

2. Coromilas EJ, Kochav S, Goldenthal I, Biviano A, Garan H, Goldbarg S, Kim JH, Yeo I, Tracy C, Ayanian S, Akar J, Singh A, Jain S, Zimerman L, Pimentel M, Osswald S, Twerenbold R, Schaerli N, Crotti L, Fabbri D, Parati G, Li Y, Atienza F, Zatarain E, Tse G, Leung KSK, Guevara-Valdivia ME, Rivera-Santiago CA, Soejima K, De Filippo P, Ferrari P, Malanchini G, Kanagaratnam P, Khawaja S, Mikhail GW, Scanavacca M, Abrahao Hajjar L, Rizerio B, Sacilotto L, Mollazadeh R, Eslami M, Laleh Far V, Mattioli AV, Boriani G, Migliore F, Cipriani A, Donato F, Compagnucci P, Casella M, Dello Russo A, Coromilas J, Aboyme A, O'Brien CG, Rodriguez F, Wang PJ, Naniwadekar A, Moey M, Kow CS, Cheah WK, Auricchio A, Conte G, Hwang J, Han S, Lazzerini PE, Franchi F, Santoro A, Capecchi PL, Joglar JA, Rosenblatt AG, Zardini M, Bricoli S, Bonura
R, Echarte-Morales J, Benito-Gonzalez T, Minguito-Carazo C, FernandezVazquez F, Wan EY (2021) Worldwide Survey of COVID-19-Associated Arrhythmias. Circ Arrhythm Electrophysiol 14:e009458. https://doi.org/10. 1161/CIRCEP.120.009458

3. Cheng MP, Cau A, Lee TC, Brodie D, Slutsky A, Marshall J, Murthy S, Lee T, Singer J, Demir KK, Boyd J, Ohm H, Maslove D, Goffi A, Bogoch, II, Sweet DD, Walley KR, Russell JA, Angiotensin Receptor Blocker Coronavirus Study Cl, (2021) Acute Cardiac Injury in Coronavirus Disease 2019 and Other Viral Infections-A Systematic Review and Meta-Analysis. Crit Care Med April 19. https://doi.org/10.1097/CCM.0000000000005026.

4. Santoso A, Pranata R, Wibowo A, Al-Farabi MJ, Huang I, Antariksa B (2021) Cardiac injury is associated with mortality and critically ill pneumonia in COVID-19: a meta-analysis. Am J Emerg Med 44:352-357. https://doi.org/10. 1016/j.jem.2020.04.052

5. Ruan Q, Yang K, Wang W, Jiang L, Song J (2020) Clinical predictors of mortality due to COVID-19 based on an analysis of data of 150 patients from Wuhan, China. Intensive Care Med 46:846-848. https://doi.org/10.1007/ s00134-020-05991-X

6. Kite TA, Ludman PF, Gale CP, Wu J, Caixeta A, Mansourati J, Sabate M, Jimenez-Quevedo P, Candilio L, Sadeghipour P, Iniesta AM, Hoole SP, Palmer N, Ariza-Sole A, Namitokov A, Escutia-Cuevas HH, Vincent F, Tica O, Ngunga M, Meray I, Morrow A, Arefin MM, Lindsay S, Kazamel G, Sharma V, Saad A, Sinagra G, Sanchez FA, Roik M, Savonitto S, Vavlukis M, Sangaraju S, Malik IS, Kean S, Curzen N, Berry C, Stone GW, Gersh BJ, Gershlick AH, International C-ACSRI, (2021) International Prospective Registry of Acute Coronary Syndromes in Patients With COVID-19. J Am Coll Cardiol 77: 2466-2476. doi: https://doi.org/10.1016/j.jacc.2021.03.309

7. Bull TM, Clark B, McFann K, Moss M, National Institutes of Health/National Heart L, Blood Institute AN, (2010) Pulmonary vascular dysfunction is associated with poor outcomes in patients with acute lung injury. Am J Respir Crit Care Med 182: 1123-1128. doi: https://doi.org/10.1164/rccm.201002-02500C

8. Jonigk D, Markl B, Helms J (2021) COVID-19: what the clinician should know about post-mortem findings. Intensive Care Med 47:86-89. https://doi.org/ 10.1007/s00134-020-06302-0

9. Helms J, Severac F, Merdji H, Angles-Cano E, Meziani F (2020) Prothrombotic phenotype in COVID-19 severe patients. Intensive Care Med 46:1502-1503. https://doi.org/10.1007/s00134-020-06082-7

10. Pesce M, Agostoni P, Botker HE, Brundel B, Davidson SM, De Caterina R, Ferdinandy P, Girao H, Gyongyosi M, Hulot JS, Lecour S, Perrino C, Schulz R, Sluijter JPG, Steffens S, Tancevski I, Gollmann-Tepekoylu C, Tschope C, van Linthout S, Madonna R, (2021) COVID-19 related cardiac complications from clinical evidences to basic mechanisms. Opinion paper of the ESC Working Group on Cellular Biology of the Heart. Cardiovasc Res 12; cvab201. doi: https://doi.org/10.1093/cvr/cvab201.

11. Bozkurt B, Kamat I, Hotez PJ, (2021) Myocarditis with COVID-19 mRNA Vaccines. Circulation Jul 20. https://doi.org/10.1161/CIRCULATIONAHA.121. 056135. Online ahead of print.

12. Sultanian $P$, Lundgren $P$, Stromsoe $A$, Aune $S$, Bergstrom $G$, Hagberg E, Hollenberg J, Lindqvist J, Djarv T, Castelheim A, Thoren A, Hessulf F, Svensson L, Claesson A, Friberg H, Nordberg P, Omerovic E, Rosengren A, Herlitz J, Rawshani A (2021) Cardiac arrest in COVID-19: characteristics and outcomes of in- and out-of-hospital cardiac arrest. A report from the Swedish Registry for Cardiopulmonary Resuscitation. Eur Heart J 42:1094-1106. https://doi. org/10.1093/eurheartj/ehaa1067

13. Sandroni C, Skrifvars MB, Nolan JP (2021) The impact of COVID-19 on the epidemiology, outcome and management of cardiac arrest. Intensive Care Med 47:602-604. https://doi.org/10.1007/s00134-021-06369-3

14. Feldstein LR, Rose EB, Horwitz SM, Collins JP, Newhams MM, Son MBF, Newburger JW, Kleinman LC, Heidemann SM, Martin AA, Singh AR, Li S, Tarquinio KM, Jaggi P, Oster ME, Zackai SP, Gillen J, Ratner AJ, Walsh RF, Fitzgerald JC, Keenaghan MA, Alharash H, Doymaz S, Clouser KN, Giuliano JS, Jr., Gupta A, Parker RM, Maddux AB, Havalad V, Ramsingh S, Bukulmez H, Bradford TT, Smith LS, Tenforde MW, Carroll CL, Riggs BJ, Gertz SJ, Daube A, Lansell A, Coronado Munoz A, Hobbs CV, Marohn KL, Halasa NB, Patel MM, Randolph AG, Overcoming C-I, Team CC-R, (2020) Multisystem Inflammatory Syndrome in U.S. Children and Adolescents. N Engl J Med 383: 334-346. https://doi.org/10.1056/NEJMoa2021680

15. Fayol A, Livrozet M, Boutouyrie P, Khettab H, Betton M, Tea V, Blanchard A, Bruno RM, Hulot JS, Ccsg F (2021) Cardiac performance in patients hospitalized with COVID-19: a 6 month follow-up study. ESC Heart Fail 8:2232-2239. https://doi.org/10.1002/ehf2.13315 